\title{
PENGARUH KUALITAS ATRIBUT PRODUK PARIWISATA TERHADAP KEPUTUSAN BERKUNJUNG WISATAWAN KE KABUPATEN SUMEDANG
}

\author{
Taufik Abdullah ${ }^{1)}$ \\ Manajemen Pemasaran Pariwisata, Universitas Pendidikan \\ Indonesia \\ Taufansyah Firdaus ${ }^{2)}$ \\ Manajemen Usaha Akomodasi / Perhotelan, STIEPAR Yapari \\ Aktripa
}

\begin{abstract}
ABSTRAK
Pariwisata merupakan salah satu sektor penggerak perekonomian suatu daerah. Semenjak adanya peraturan tentang otonomi daerah, setiap kabupaten dan kota berusaha untuk meningkatkan perekonomiannya dengan mengandalkan kegiatan pariwisata. Kabupaten Sumedang juga termasuk daerah yang turut serta mengembangkan pariwisatanya, hanya saja kondisi yang terjadi adalah kepariwisataan di Kabupaten Sumedang tidak se-booming kabupaten lainnya. Perlu adanya upaya meningkatkan jumlah wisatawan yang datang ke Sumedang. Penelitian ini bertujuan untuk mengetahui upaya meningkatkan keputusan berkunjung wisatawan domestik ke Kabupaten Sumedang melalui kualitas atribut produk pariwisata. Jenis penelitian ini adalah penelitian eksplanatori, dengan jumlah 250 responden. Hasil kuesiner dianalisis dengan analisis korelasi, koefisien determinasi dan regresi linier berganda. Hasil penelitian ini adalah terdapat pengaruh kualitas atribut produk pariwisata terhadap keputusan berkunjung wisatawan ke Kabupaten Sumedang. Terdapat variasi besaran pengaruh dari masingmasing sub variabel kualitas atribut produk pariwisata.
\end{abstract}

Kata Kunci: Atribut Produk Pariwisata, Keputusan Berkunjung 


\title{
THE INFLUENCE OF TOURISM PRODUCT'S ATTRIBUTES QUALITYTOWARDS DOMESTIC TRAVELERS VISITING DECISIONS TO SUMEDANG REGENCY
}

\begin{abstract}
Tourism is one of the economy driving sectors in a region. Since the rules on regional autonomy is proclaimed, every regency and city are trying to improve its economy by relying on tourism activities. Sumedang Regency is also become one region that participate in developing tourism, but a condition that occurs in Sumedang is that the tourism sectors is not as famous as other region. Efforts are needed to increase the number of tourists coming to Sumedang. This study aims to determine an effort to Improve Domestic Travelers Visiting Decisions to Sumedang Regency Through the Quality of Tourism Product's Attributes. This type of research is explanatory research with 250 respondents. The results of questionnaires were analyzed by correlation analysis, determination coefficient and multiple linear regression. The results of this research is there is an influence of the quality of the tourism product's attributes against the tourist's decision of visiting to Sumedang Regency. There are variations in the amount of influence of each sub variable quality of the tourism product's attributes.
\end{abstract}

Keywords: Tourism Product's Attributes, Visiting Decisions

\section{PENDAHULUAN}

Sumedang merupakan salah satu kabupaten di Provinsi Jawa Barat yang kaya akan budaya. Dengan diapit oleh kabupatenkabupaten lainnya di Provinsi yang sama, menjadikan kabupaten ini jalur lintasan sehingga banyak pengunjung yang melewati kabupaten Sumedang. Berdasarkan Perda No. 2 Tahun 2008 Tentang Rencana Pembangunan Jangka Panjang Daerah (RPJPD) 
Tahun 2005-2025. Visi jangka panjang Kabupaten Sumedang adalah "Kabupaten Sumedang Sejahtera, Agamis, dan Demokratis pada Tahun 2025". Visi tersebut dapat diringkas menjadi "SUMEDANG SEHATI". Visi tersebut tentunya dibuat berdasarkan kebutuhan Kabupaten Sumedang. Masyarakat yang sejahtera, demokratis dan didasari dengan pengamalan nilai-nilai agama yang kuat merupakan tujuan utama pemerintah kabupaten Sumedang. Visi tersebut dapat tercapai apabila didukung dengan misi yang tepat. Salah satu misi jangka menengah yang termasuk dalam 5 (lima) misi pembangunan Kabupaten Sumedang yang tertera dalam Perda No. 2 Tahun 2008 Tentang Rencana Pembangunan Jangka Panjang Daerah (RPJPD) Tahun 20052025 yaitu "Mewujudkan Perekonomian Daerah yang Tangguh dan Berkelanjutan yang Berbasis pada Agribisnis, Pariwisata dan industri". Melalui misi tersebut dapat diketahui bahwa pariwisata merupakan salah satu yang ingin dikembangkan oleh Pemerintah Kabupaten Sumedang. Atraksi wisata yang ditawarkan di Kabupaten Sumedang sudah cukup banyak, mulai dari wisata alam berupa pegunungan, perkebunan, pertanian, sungai, sumber air panas, dan sebagainya. Pada atraksi wisata Budaya, Sumedang memiliki berbagai hasil kebudayaan dalam bentuk makanan dan minuman, museum, situs makam leluhur, museum hingga peninggalan Goa Jepang.

Jika dibandingkan dengan kabupaten lainnya, Sumedang memang masih kurang begitu dikenal sebagai destinasi wisata utama. Tetapi melalui misi pemerintah yang jelas menyatakan bahwa pariwisata merupakan sektor yang diharapkan dalam memajukan perekonomian Sumedang. Selain itu dengan sedang dibangunnya infrastruktur jalan Tol, serta dengan mulai digenangnya Waduk Jatigede yang merupakan bendungan terbesar kedua di Indonesia. Sumedang memiliki kesempatan cukup besar menjadi destinasi wisata unggulan di Provinsi Jawa Barat. Keberadaan Waduk Jatigede diharapkan dapat menjadi pemicu majunya kegiatan pariwisata di Sumedang, karena akan banyak atraksi wisata yang dapat dibangun dengan adanya bendungan tersebut. Berdasarkan data yang didapat dari BPS Provinsi Jawa Barat, mengenai jumlah kunjungan wisatawan ke akomodasi di Jawa Barat di tahun 2011. Jumlah wisatawan yang 
mengunjungi Kabupaten Sumedang masih di bawah kabupaten lainnya di Jawa Barat, yaitu totalnya sebanyak 50.835 wisatawan. Angka tersebut lebih rendah dari pada jumlah wisatawan yang ke Kabupaten Garut, Kuningan, Bogor dan sebagainya. Jumlah wisatawan yang masih rendah akan berdampak terhadap perkembangan sektor kepariwisataan di Kabupaten Sumedang. Hal ini jelas dikarenakan wisatawan merupakan pasar yang akan membelanjakan uangnya sehingga pergerakkan ekonomi di suatu destinasi dapat lebih hidup. Dengan kata lain tanpa adanya pengunjung yang datang ke suatu destinasi, maka kegiatan pariwisata tidak akan ada.

Berbagai hal dapat menjadi penyebab wisatawan mengunjungi suatu destinasi wisata. Namun, tentunya wisatawan akan menilai terlebih dahulu apakah alternatif destinasi yang ada di pilihannya sudah layak atau tidak untuk dikunjungi. Mereka perlu memastikan dari segi kemenarikan atraksi wisatanya sudah sesuai dengan apa yang dibutuhkannya, selain itu juga apakah fasilitas pendukung transportasi dan aksesibilitas telah memadai, dan juga tidak luput apakah masyarakat lokal ramah terhadap wisatawan yang berkunjung ke daerahnya. Dalam mengembangkan suatu destinasi perlu adanya integrasi pada semua lini, tidak hanya antar dinas terkait pada pemerintah, tetapi juga koordinasi perlu dilakukan dengan pelaku industri swasta di destinasi tersebut, serta tidak luput kerjasama dari masyarakat lokal. Ketika seluruh pihak telah terintegrasi maka pembangunan akan sinergis sesuai dengan kebutuhan seluruh stakeholder pariwisata di destinasi wisata tersebut. Jika hal tersebut telah terjadi, maka berbagai poin atribut produk pariwisata di suatu destinasi akan terlihat baik mulai dari atraksi, fasilitas, transportasinya bahkan jika disertai dengan pengembangan dari segi sumber daya manusia maka hospitality juga akan dirasakan baik oleh wisatawan. Penelitian ini dilakukan untuk mengetahui pengaruh kualitas atribut produk pariwisata terhadap keputusan berkunjung wisatawan ke Kabupaten Sumedang.

\section{KAJIAN PUSTAKA}

Telah banyak ahli menyampaikan berbagai definisi pariwisata, namun kecenderungannya lebih kepada pariwisata 
sebagai suatu fenomena, kegiatan dan ilmu. Salah satunya seperti yang disampaikan oleh Goeldner dan Ritchie (2009: 6)

Tourism may be defined as the processes, activities, and outcomes arising from the relationships and the interactions among tourists, tourism suppliers, host governments, host communities, and surrounding environments that are involved in the attracting and hosting of visitors.

Pariwisata bisa diartikan sebagai suatu proses, aktivitas, dan hasil akhir yang muncul dari hubungan dan interaksi antara wisatawan, penyedia jasa pariwisata, pemerintah lokal, masyarakat lokal dan lingkungan sekitarnya yang terlibat dalam menarik dan melayani pengunjung. Definisi tersebut menjelaskan bahwa pariwisata merupakan suatu proses ataupun kegiatan, dimana terjadi interkasi antara berbagai pemangku kepentingan di dalam pariwisata itu sendiri. Pada saat masyarakat lokal, pemerintah setempat dan penyedia jasa pariwisata saling mengisi dalam menarik agar wisatawan datang ke destinasi wisata kemudian mereka melayani wisatawan tersebut, saat itulah kegiatan pariwisata terjadi. tabel berikut:

Beberapa definisi pariwisata lainnya dapat dilihat pada

\section{Tabel 1}

\section{Definisi Parwisata Dari Berbagai Ahli}

\begin{tabular}{|l|l|}
\hline \multicolumn{1}{|c|}{ Ahli } & \multicolumn{1}{|c|}{ Definisi Pariwisata } \\
\hline $\begin{array}{l}\text { Hunziker (1951, } \\
\text { in Collier 1997, p. } \\
\text { 2) }\end{array}$ & $\begin{array}{l}\text { arising from of the phenomena and relationships } \\
\text { in so far as they do not lead to permanent } \\
\text { residence and are not connected with any earning } \\
\text { activity. }\end{array}$ \\
& $\begin{array}{l}\text { Sejumlah fenomena dan hubungan yang muncul } \\
\text { dari kegiatan perjalanan dan tinggal di daerah } \\
\text { bukan tempat tinggal, Selama tidak untuk } \\
\text { mengarah pada tinggal secara permanen dan tidak } \\
\text { berhubungan dengan aktivitas mencari pendapatan. }\end{array}$ \\
\hline
\end{tabular}




\begin{tabular}{|c|c|}
\hline Ahli & Definisi Pariwisata \\
\hline $\begin{array}{l}\text { Leiper, (1979, p. } \\
\text { 403-404) }\end{array}$ & $\begin{array}{l}\text { It is the system involving the discretionary travel } \\
\text { and temporary stay of persons away from their } \\
\text { usual place of residence for one or more nights, } \\
\text { excepting tours made for the primary purpose of } \\
\text { earning remuneration from points en route. } \\
\text { Pariwisata adalah suatu sistem yang termasuk di } \\
\text { dalamnya orang melakukan perjalanan dengan } \\
\text { leluasa dan tinggal sementara di luar daerah tempat } \\
\text { tinggalnya selama satu malam atau lebih, } \\
\text { terkecuali tur yang dibuat untuk tujuan utama } \\
\text { mendapatkan remunerasi dari titik perjalanan }\end{array}$ \\
\hline $\begin{array}{l}\text { Mill \& Morrison } \\
\text { (1992, p. 9) }\end{array}$ & $\begin{array}{l}\text { Tourism is the term given to the activity that } \\
\text { occurs when people travel. This encompasses } \\
\text { everything from the planning of the trip, the travel } \\
\text { to the destination area, the stay itself, the return } \\
\text { and the reminiscences about it afterwards. It } \\
\text { includes the activities the traveller undertakes as } \\
\text { part of the trip, the purchases made, and the } \\
\text { interactions that occur between host and guest in } \\
\text { the destination area. In sum it is all of the } \\
\text { activities and impacts that occur when a visitor } \\
\text { travels. } \\
\text { Pariwisata adalah suatu istilah yang diberikan } \\
\text { untuk kegiatan yang terjadi ketika orang } \\
\text { melakukan perjalanan. Hal ini meliputi semuanya, } \\
\text { dari perencanaan trip, perjalanan ke area destinasi, } \\
\text { tinggal di area tersebut, kembali dan mengenang } \\
\text { kembali setelahnya. } \\
\text { Ini mencakup kegiatan yang dilakukan wisatawan } \\
\text { sebagai bagian dari perjalanan, pembelian yang } \\
\text { dilakukan, dan interaksi yang terjadi antara tuan } \\
\text { rumah dan tamu di daerah tujuan. Singkatnya itu } \\
\text { adalah semua kegiatan dan dampak yang terjadi } \\
\text { ketika pengunjung melakukan perjalanan }\end{array}$ \\
\hline Heath \& & The study of tourism is the study of people away \\
\hline
\end{tabular}




\begin{tabular}{|c|c|}
\hline Ahli & Definisi Pariwisata \\
\hline$(1992$, p. 4$)$ & $\begin{array}{l}\text { from their usual habitat, of the establishments that } \\
\text { respond to the requirements of travellers, and of } \\
\text { the impacts they have on the economic, physical, } \\
\text { and social well-being of their hosts. It involves the } \\
\text { motivations and experiences of the tourists, the } \\
\text { expectations of and adjustments made by residents } \\
\text { of reception areas, and the roles played by the } \\
\text { numerous agencies and institutions that intercede } \\
\text { between them. } \\
\text { Studi pariwisata adalah studi tentang orang-orang } \\
\text { di luar habitat mereka yang biasa, mengenai } \\
\text { perusahaan/ instansi yang merespon kebutuhan } \\
\text { wisatawan, dan dampak yang mereka timbulkan } \\
\text { pada ekonomi, fisik, dan kesejahteraan sosial pada } \\
\text { masyarakat lokal. Hal ini melibatkan motivasi dan } \\
\text { pengalaman dari para wisatawan, harapan dan } \\
\text { penyesuaian yang dilakukan oleh penduduk daerah } \\
\text { penerimaan, dan peran yang dimainkan oleh } \\
\text { berbagai lembaga dan institusi yang ada di antara } \\
\text { mereka }\end{array}$ \\
\hline $\begin{array}{l}\text { Holloway (1994, } \\
\text { p. 3) }\end{array}$ & $\begin{array}{l}\text {... someone who travels to see something different, } \\
\text { and then complains when he finds things are not } \\
\text { the same! } \\
\text {... Seseorang yang melakukan perjalanan untuk } \\
\text { melihat sesuatu yang berbeda, dan mengeluh } \\
\text { ketika mereka menemukan sesuatu yang berbeda! }\end{array}$ \\
\hline Gunn $(1994$, p. 4) & $\begin{array}{l}\text {... tourism is defined as encompassing all travel } \\
\text { with the exception of commuting. } \\
\text { Pariwisata didefinisikan meliputi seluruh } \\
\text { perjalanan terkecuali berangkat dan pulang kerja. }\end{array}$ \\
\hline $\begin{array}{l}\text { WTO }(1995, \quad p . \\
12)\end{array}$ & $\begin{array}{l}\text {... the activities of persons travelling to and } \\
\text { staying in places outside their usual environment } \\
\text { for not more than one consecutive year for } \\
\text { leisure, business and other purposes. }\end{array}$ \\
\hline
\end{tabular}




\begin{tabular}{|l|l|}
\hline \multicolumn{1}{|c|}{ Ahli } & \multicolumn{1}{|c|}{ Definisi Pariwisata } \\
\hline Hall (1998, p. 6) & $\begin{array}{l}\text { Kongiatan seseorang melakukan perjalanan ke } \\
\text { dan tinggal di tempat di luar lingkungannya selama } \\
\text { tidak lebih dari satu tahun untuk bersenang-senang, } \\
\text { bisnis dan tujuan lainnya. } \\
\text { industrial society which involves a person, either } \\
\text { individually or in a group, travelling from place to } \\
\text { place (the physical component of tourism), and/or } \\
\text { journeying from one psychological state to } \\
\text { another the re-creating component of tourism). }\end{array}$ \\
$\begin{array}{l}\text { Pariwisata adalah suatu fenomena komersial dari } \\
\text { masyarakat industri yang melibatkan seseorang, } \\
\text { baik individu ataupun kelompok, melakukan } \\
\text { perjalanan dari satu tempat ke tempat lainnya } \\
\text { komponen fisik dari pariwisata), dan/atau } \\
\text { menjelajah dari satu kondisi psikologis ke kondisi } \\
\text { lainnya (komponen rekreasi dari pariwisata). }\end{array}$ \\
\hline $\begin{array}{l}\text { Sharpley (2002, p. } \\
\text { 22) }\end{array}$ & $\begin{array}{l}\text { "It is, in short, a social phenomenon which } \\
\text { involves the movement of people to various } \\
\text { destinations and their (temporary) stay there." }\end{array}$ \\
$\begin{array}{l}\text { Pariwisata, singkatnya, suatu fenomena sosial yang } \\
\text { mencakup pergerakkan manusia ke destinasi dan } \\
\text { tinggal di tempat tersebut sementara waktu. }\end{array}$ \\
\hline
\end{tabular}

Sumber: Pike (2008, hlm. 21)

Istilah pariwisata ini juga sering disalah gunakan kata rekreasi, seperti yang dijelaskan Mill (2010: 23) yaitu, "the term "recreation" overlaps in many ways with tourism. Recreation is what happens during an individual's leisure time". Menurut Mill rekreasi itu sendiri adalah apa yang terjadi selama waktu luang seseorang, sehingga aktivitas yang dilakukan untuk mengisi waktu luang adalah rekreasi.

Dalam berwisata, wisatawan menikmati berbagai produk pariwisata, produk pariwisata tersebut merupakan gabungan dari berbagai produk barang maupun jasa yang ada di industri 
pariwisata. Burkart and Medlik, 1974 dalam Vanhove (2005: 11), menyatakan bahwa "The tourist product is an amalgam of what he does at the destination and the services he uses to make it possible". Sehingga berdasarkan pendapat tersebut, produk untuk wisatawan adalah keseluruhan yang dilakukannya di destinasi dan pelayanan yang digunakannya agar seluruh kegiatannya terlaksana.

Vanhove (2005: 79) menjelaskan lebih lanjut bahwa pada sisi konsumen, produk pariwisata adalah seluruh pengalaman dari mereka meninggalkan rumah hingga mereka kembali. Berikut kutipannya, "from the point of view of consumers, the tourism product is the total experience from the moment they leave home until they return". Jika merujuk pada pernyataan di atas, seluruh pengalaman wisatawan dari mulai dirinya menaiki transportasi berangkat menuju destinasi, diteruskan segala kegiatan yang dilakukan dan pengalaman yang dirasakannya, termasuk kenyamanan jalan, masyarakat yang ramah, destinasi yang aman dan sebagainya, hingga dirinya kembali ke tempat asalnya adalah gabungan produk-produk pariwisata.

Berikutnya adalah apabila mengingat kegiatan parwisata sangatlah kompleks, maka untuk menyederhanakannya perlu ada tolak ukur atribut produk pariwisata. Berbagai ahli tentunya menyatakan berbagai pendapatnya mengenai atribut produk pariwisata. Salah satunya adalah Buhalis (2000: hlm. 98) yang menyatakan bahwa atribut produk pariwisata diantaranya adalah attractions (atraksi wisata), amenities (fasilitas), accessibility (aksesibilitas), activities (aktifitas), available packages (ketersediaan paket), dan ancillary services (layanan tambahan).

Sedangkan atribut produk pariwisata menurut Holloway, Humphreys dan Davidson (2009: 15) yaitu attractions, amenities dan accessibility, selain itu mereka menambahkan penjelasan bahwa "all destinations require adequate attractions, amenities and accessibility if they are to appeal to large numbers of tourists". Jika diterjemahkan yaitu semua destinasi memerlukan atraksi, amenitis, dan aksesibilitas yang memadai apabila mereka ingin menarik jumlah wisatawan yang banyak.

Pada penelitian ini dimensi kualitas atribut produk pariwisata yang digunakan adalah berdasarkan Mill (2010: 23). 
Mill menyatakan "there are four major dimensions to tourism: attractions, facilities, transportation, and hospitality". Terdapat empat dimensi pariwisata yaitu attractions, facilities, transportation, dan hospitality.

Elemen utama dari jalannya kegiatan pariwisata di suatu daerah adalah ditandai dengan adanya pengunjung yang datang ke daerah tersebut, yang otomatis jika suatu destinasi tidak pernah dikunjungi pengunjung, maka secara praktis tidak ada kegiatan pariwisata sama sekali. Banyak atau tidaknya jumlah wisatawan bergantung pada seberapa besar keputusan berkunjung calon wisatawan sebelum mengunjungi destinasi.

Keputusan berunjung merujuk pada konsep keputusan pembelian konsumen yang diadaptasi menjadi keputusan berkunjung wisatawan. Menurut Solomon (2013: 294), " $a$ purchase decision actually is composed of a series of stages that results in the selection of one product over competing options". Suatu keputusan pembelian sebenarnya adalah terdiri dari serangkaian tahapan yang menghasilkan pemilihan satu produk atas pilihan bersaing. Bahasan keputusan pembelian termasuk ke dalam perilaku konsumen seperti yang juga dijelaskan oleh Solomon (2013: 294).

Consumer decision making is a central part of consumer behavior, but the way we evaluate and choose products (and the amount of thought we put into these choices) varies widely, depending on such dimensions as the degree of novelty or risk in the decision.

Pembuatan keputusan konsumen adalah bagian pusat dari perilaku konsumen, tetapi cara kita mengevaluasi dan memilih produk (dan sejumlah pikiran yang kita curahkan ke dalam pilihan ini) sangat bervariasi, tergantung pada dimensi seperti tingkat kebaruan atau risiko dalam pembuatan keputusan.

Menurut Lancaster dan Reynolds (2005: 56), "consumer behaviour can be defined as: The acts of individuals directly involved in obtaining and using economic goods and services, including the decision processes that precede and determine these acts". Jika diartikan maka perilaku konsumen dapat didefinisikan sebagai suatu tindakan individu yang secara 
langsung meliputi mendapatkan dan menggunakan barang dan jasa ekonomi, termasuk proses keputusan yang mendahului dan menentukan tindakan ini.

Bowie dan Buttle (2004, hlm. 61) menjelaskan proses keputusan konsumen pada produk hospitality industry. Dimana Hospitality Consumer Decision-making Process for a Complex Product terdiri dari; 1) Perception of need, yaitu persepsi calon wisatawan akan kebutuhan untuk berwisata dimana terjadi ketidakseimbangan yang memunculkan adanya kebutuhan tersebut, 2) Information search, adalah tahap dimana calon wisatawan akan mencari tahu berbagai informasi destinasi yang dapat memenuhi kebutuhannya, 3) Evaluation of alternatives, Tahap mengevaluasi berbagai alternatif yang tidak hanya destinasii, tetapi juga transportasi yang digunakan, akomodasi dan sebagainya, 4) Purchase, merupakan kegiatan membeli produk pariwisata dengan pertimbangan produk, brand, jumlah pembelian, waktu pembelian dan metode pembayaran, serta 5) Post-purchase evaluation, tahap evaluasi setelah pembelian ini akan menjadi pertimbangan masa depan wisatawan untuk mengunjungi kembali atau tidak dan menyebarkan informasi yang positif atau negatif mengenai destinasi yang telah dikunjungi.

Dimensi untuk mengukur keputusan berkunjung dalam penelitian ini merujuk kepada peryataan Pike (2008: 212) yaitu, "decisions must be made about where to go, when to go, how to get there and what to do there". Keputusan harus dibuat mengacu kepada kemana akan pergi, kapan akan pergi, bagaimana cara sampai di sana, dan apa yang akan dilakukan di sana.

\section{METODOLOGI PENELITIAN}

Penelitian ini termasuk dalam penelitian eksplanatori karena yang diteliti adalah pengaruh dari variabel bebas terhadap variabel terikat. Seperti menurut pendapat dari Silalahi (2012: 30), "penelitian eksplanatori atau eksplanatif atau eksplanasi bertujuan untuk menjelaskan hubungan antara dua atau lebih gejala atau variabel". Lebih lanjut Silalahi juga menjelaskan 
bahwa penelitian eksplanasi ini lebih dikenal dengan nama penelitian korelasional.

Operasionalisasi variabel dibuat untuk mendapatkan kerangkan dalam menentukan item pertanyaan/pernyataan pada kuesioner. Tabel di bawah ini adalah operasionalisasi variabel yang digunakan dalam penelitian.

Tabel 2

Operasionalisasi Variabel

\begin{tabular}{|c|c|c|c|c|c|}
\hline Variabel & $\begin{array}{c}\text { Sub } \\
\text { Variabel }\end{array}$ & Indikator & Ukuran & Skala & No. Item \\
\hline \multirow{12}{*}{$\begin{array}{c}\text { Kualitas } \\
\text { Atribut } \\
\text { Produk } \\
\text { Pariwisata (X) } \\
\text { Mill (2010, } \\
\text { hlm. 23) }\end{array}$} & \multicolumn{5}{|c|}{$\begin{array}{l}\text { "The tourism product is the total experience from the moment they leave home } \\
\text { until they return" Vanhove }(2005, \mathrm{hlm} .79)\end{array}$} \\
\hline & \multirow{5}{*}{$\begin{array}{c}\text { Attractio } \\
n s \\
\left(X_{1}\right)\end{array}$} & $\begin{array}{l}\text { Cultural } \\
\text { Attractions }\end{array}$ & $\begin{array}{l}\text { Kemenarikan budaya } \\
\text { Kabupaten Sumedang }\end{array}$ & Ordinal & 1 \\
\hline & & $\begin{array}{l}\text { Natural } \\
\text { Attractions }\end{array}$ & $\begin{array}{l}\text { Kemenarikan alam } \\
\text { Kabupaten Sumedang }\end{array}$ & Ordinal & 2 \\
\hline & & Events & $\begin{array}{l}\text { Kemenarikan } \\
\text { acara/event di Kabupaten } \\
\text { Sumedang }\end{array}$ & Ordinal & 3 \\
\hline & & Recreation & $\begin{array}{l}\text { Kemenarikan kegiatan } \\
\text { rekreasi di Kabupaten } \\
\text { Sumedang }\end{array}$ & Ordinal & 4 \\
\hline & & $\begin{array}{l}\text { Entertainm } \\
\text { ent } \\
\text { Attractions }\end{array}$ & $\begin{array}{l}\text { Kemenarikan pusat } \\
\text { hiburan di Kabupaten } \\
\text { Sumedang }\end{array}$ & Ordinal & 5 \\
\hline & \multirow[t]{4}{*}{$\begin{array}{c}\text { Facilities } \\
\left(X_{2}\right)\end{array}$} & $\begin{array}{l}\text { Lodging } \\
\text { Places }\end{array}$ & $\begin{array}{l}\text { Kondisi dan ketersediaan } \\
\text { Hotel ataupun } \\
\text { Penginapan di } \\
\text { Kabupaten Sumedang }\end{array}$ & Ordinal & 6 \\
\hline & & Restaurants & $\begin{array}{l}\text { Kondisi dan ketersediaan } \\
\text { Restoran dan Rumah } \\
\text { Makan di Kabupaten } \\
\text { Sumedang }\end{array}$ & Ordinal & 7 \\
\hline & & $\begin{array}{l}\text { Support } \\
\text { Services }\end{array}$ & $\begin{array}{l}\text { Kondisi dan ketersediaan } \\
\text { Fasilitas Pendukung } \\
\text { kegiatan wisata di } \\
\text { Kabupaten Sumedang }\end{array}$ & Ordinal & 8 \\
\hline & & $\begin{array}{l}\text { Infrastructu } \\
\text { res }\end{array}$ & $\begin{array}{l}\text { Kondisi infrastruktur di } \\
\text { Kabupaten Sumedang }\end{array}$ & Ordinal & 9 \\
\hline & \multirow[t]{2}{*}{$\begin{array}{c}\text { Transpor } \\
\text { tation } \\
\left(X_{3}\right)\end{array}$} & To the City & $\begin{array}{l}\text { Kondisi dan } \\
\text { Ketersediaan transportasi } \\
\text { menuju Kabupaten } \\
\text { Sumedang }\end{array}$ & Ordinal & 10 \\
\hline & & $\begin{array}{l}\text { Between } \\
\text { the } \\
\text { destinations }\end{array}$ & $\begin{array}{l}\text { Kondisi dan } \\
\text { Ketersediaan transportasi } \\
\text { antar destinasi wisata di } \\
\text { Kabupaten Sumedang }\end{array}$ & Ordinal & 11 \\
\hline
\end{tabular}




\begin{tabular}{|c|c|c|c|c|c|}
\hline Variabel & $\begin{array}{c}\text { Sub } \\
\text { Variabel }\end{array}$ & Indikator & Ukuran & Skala & No. Item \\
\hline & $\begin{array}{c}\text { Hospitali } \\
\text { ty } \\
\left(X_{4}\right)\end{array}$ & $\begin{array}{l}\text { Local } \\
\text { Community }\end{array}$ & $\begin{array}{l}\text { Keramahtamahan dan } \\
\text { penerimaan masyarakat } \\
\text { lokal Kabupaten } \\
\text { Sumedang }\end{array}$ & Ordinal & 12 \\
\hline & & $\begin{array}{l}\text { Industries } \\
\text { Employees }\end{array}$ & $\begin{array}{l}\text { Keramahtamahan dan } \\
\text { penerimaan pegawai } \\
\text { swasta di Kabupaten } \\
\text { Sumedang }\end{array}$ & Ordinal & 13 \\
\hline & & $\begin{array}{l}\text { Governmen } \\
t \\
\text { Employees }\end{array}$ & $\begin{array}{l}\text { Keramahtamahan dan } \\
\text { penerimaan pegawai } \\
\text { pemerintahan Kabupaten } \\
\text { Sumedang }\end{array}$ & Ordinal & 14 \\
\hline \multirow{9}{*}{$\begin{array}{c}\text { Keputusan } \\
\text { Berkunjung } \\
\text { (Y) } \\
\text { Pike (2008, } \\
\text { hlm. 212) }\end{array}$} & \multicolumn{5}{|c|}{$\begin{array}{l}\text { "A purchase decision actually is composed of a series of stages that results in the } \\
\text { selection of one product over competing options" Solomon }(2013, \mathrm{hlm} .294)\end{array}$} \\
\hline & & \multirow[t]{2}{*}{$\begin{array}{l}\text { Where to } \\
\text { go }\end{array}$} & $\begin{array}{l}\text { Tingkat pemilihan } \\
\text { Sumedang sebagai } \\
\text { destinasi utama }\end{array}$ & Ordinal & 15 \\
\hline & & & $\begin{array}{l}\text { Jumlah destinasi yang } \\
\text { dikunjungi ketika di } \\
\text { Sumedang }\end{array}$ & Ordinal & 16 \\
\hline & & \multirow[t]{2}{*}{ When to go } & $\begin{array}{l}\text { Intensitas mengunjungi } \\
\text { ketika Hari Libur }\end{array}$ & Ordinal & 17 \\
\hline & & & $\begin{array}{l}\text { Intensitas mengunjungi } \\
\text { ketika Hari Kerja }\end{array}$ & Ordinal & 18 \\
\hline & & \multirow[t]{3}{*}{$\begin{array}{l}\text { How to get } \\
\text { there }\end{array}$} & $\begin{array}{l}\text { Tingkat penggunaan } \\
\text { Penyalur (Travel Agent) }\end{array}$ & Ordinal & 19 \\
\hline & & & $\begin{array}{l}\text { Tingkat penggunaan alat } \\
\text { transportasi Umum }\end{array}$ & Ordinal & 20 \\
\hline & & & $\begin{array}{l}\text { Tingkat penggunaan alat } \\
\text { transportasi Pribadi }\end{array}$ & Ordinal & 21 \\
\hline & & $\begin{array}{l}\text { What to do } \\
\text { there }\end{array}$ & $\begin{array}{l}\text { Jumlah aktivitas yang } \\
\text { dilakukan }\end{array}$ & Ordinal & 22 \\
\hline
\end{tabular}

Sampel yang digunakan adalah sebanyak 250 responden. Penentuan jumlah sampel sesuai dengan teknik sampling yang digunakan yaitu non probability sampling, yang secara lebih spesifik menggunakan sampling kuota. Menurut Utama dan Mahadewi (2012: 74)

Sampling kuota adalah metode memilih sampel yang mempunyai ciri-ciri tertentu dalam jumlah atau kuota yang diinginkan. Jumlah subjek yang akan diselidiki ditetapkan lebih dahulu. Jika kuota telah ditentukan mulailah penyelidikan dan tentang siapa yang akan dijadikan responden, terserah kepada team pengumpul data.

Teknik pengumpulan data yang digunakan adalah menggunakan angket/kuesioner. Setelah data terkumpul 
selanjutnya diolah dengan menggunakan teknik analisis deskriptif dan verifikatif dengan analisis korelasi, koefisien determinasi dan regresi berganda.

Maka hipotesis statistik mengenai pengaruh secara simultan yang diajukan dalam penelitian ini adalah:
$\mathrm{H}_{0}: \mathrm{F}_{\text {hitung }}<\mathrm{F}_{\text {tabel }}$,
Tidak terdapat pengaruh yang signifikan dari kualitas atribut produk pariwisata terhadap keputusan berkunjung wisatawan ke Kabupaten Sumedang.
$\mathrm{H}_{\mathrm{a}}: \mathrm{F}_{\text {hitung }}>\mathrm{F}_{\text {tabel}}$, Terdapat pengaruh yang signifikan dari kualitas atribut produk pariwisata terhadap keputusan berkunjung wisatawan ke Kabupaten Sumedang.

\section{HASIL DAN PEMBAHASAN}

Analisis korelasi pada penelitian ini menggunakan rumus korelasi Karl Pearson Product Moment. Melalui analisis korelasi yang telah dilakukan akan diketahui seberapa kuat hubungan antara variabel bebas dan variabel terikat. Berikut hasil perhitungan korelasi dengan menggunakan bantuan software IBM SPPS Statistics Ver.22.

\section{Tabel 3}

\section{Hasil Pengujian Koefisien Korelasi Dan Koefisien \\ Determinasi \\ Model Summary}

\begin{tabular}{|l|c|r|r|r|}
\hline Model & $\mathrm{R}$ & $\mathrm{R}$ Square & Adjusted R Square & Std. Error of the Estimate \\
\hline 1 & $.645^{\mathrm{a}}$ & .415 & .406 & 2.162 \\
\hline
\end{tabular}

a. Predictors: (Constant), $\mathrm{X} 4, \mathrm{X} 1, \mathrm{X} 3, \mathrm{X} 2$

Dari tabel di atas terlihat bahwa nilai korelasi kualitas atribut produk pariwisata dan keputusan berkunjung adalah 0,645. Sehingga terdapat hubungan kuat antara kualitas atribut produk pariwisata dan keputusan berkunjung wisatawan ke kabupaten Sumedang.

Melalui hasil perhitungan SPSS yang terlihat pada tabel 4.16 diketahui bahwa nilai koefisien determinasi pada penelitian 
ini adalah sebesar 0,415. Maka Keputusan berkunjung wisatawan ke Kabupaten Sumedang 41,5\% dipengaruhi oleh kualitas atribut produk pariwisata. Sisanya sebesar $58,5 \%$ dipengaruhi oleh variabel lain yang tidak diteliti dalam penelitian ini.

Pada analisis regresi berganda maka akan diketahui arah pengaruh variabel bebas terhadap variabel terikat. Selain daripada itu juga akan diketahui pengaruh dari masing-masing sub variabel bebas. Berikut hasil perhitungan analisis regresi berganda dengan bantuan software IBM SPPS Statistics Ver.22.

\section{Tabel 4}

Hasil Pengujian Analisis Regresi Berganda Coefficients $^{\mathrm{a}}$

\begin{tabular}{|c|c|c|c|c|c|}
\hline \multirow[b]{2}{*}{ Model } & \multicolumn{2}{|c|}{ Unstandardized Coefficients } & $\begin{array}{c}\text { Standardized } \\
\text { Coefficients }\end{array}$ & \multirow[b]{2}{*}{$t$} & \multirow[b]{2}{*}{ Sig. } \\
\hline & $\mathrm{B}$ & Std. Error & Beta & & \\
\hline (Constant) & 11.811 & 1.486 & & 7.947 & .000 \\
\hline $\mathrm{X} 1$ & .189 & .072 & .143 & 2.618 & .009 \\
\hline $\mathrm{X} 2$ & .423 & .088 & .320 & 4.777 & .000 \\
\hline X3 & .414 & .167 & .144 & 2.473 & .014 \\
\hline $\mathrm{X} 4$ & .450 & .119 & .233 & 3.792 & .000 \\
\hline
\end{tabular}

a. Dependent Variable: $Y$

Hasil perhitungan analisis regresi berganda dalam penelitian ini menghasilkan persamaan regresi sebagai berikut:

$$
Y=11,811+0,189 X_{1}+0,423 X_{2}+0,414 X_{3}+0,450 X_{4}
$$

Keterangan:

$\mathrm{Y}=\quad$ Keputusan

Berkunjung

$\mathrm{X}_{1}=$ Attractions

$\mathrm{X}_{2}=$ Facilities

$\mathrm{X}_{3}=$ Transportations

$\mathrm{X}_{4}=$ Hospitality 
Dalam persamaan tersebut nilai 11,811 adalah konstanta, yang artinya apabila tidak ada kenaikan nilai pada variabel bebas maka nilai keputusan berkunjung adalah 11,811. Selanjutnya apabila secara bersama-sama terjadi kenaikan nilai sebesar 1 (satu) pada setiap sub variabel bebas (attractions, facilities, transportations dan hospitality). Maka akan terjadi kenaikan sebesar $0,189+0,423+0,414+0,450=$ 1,476 pada keputusan berkunjung wisatawan ke Kabupaten Sumedang.

Melalui persamaan regresi berganda di atas, maka diketahui bahwa pengaruh terbesar adalah pada hospitality diikuti dengan fasilitas dan pengaruh ketiga terbesar adalah transportasi. Bagi keputusan wisatawan berkunjung ke Kabupaten Sumedang ternyata ketiga dimensi tersebut memegang pengaruh yang sangat penting bahkan jika dibandingkan dengan atraksi, ketiga dimensi tersebut jauh lebih besar pengaruhnya. Hal ini sangat wajar karena tentunya manusia akan lebih senang untuk mendatangi tempat yang memiliki keramahtamahan dan penerimaan yang baik. Fasilitas dan transportasi juga memegang peranan tinggi karena semenarik apapun atraksi wisata, namun apabila tidak didukung dengan fasilitas dan transportasi untuk memudahkan wisatawan, maka wisatawan akan enggan untuk berkunjung.

Pengujian hipotesis pada penelitian ini menggunakan uji signifikansi uji $\mathrm{F}$ Hasil uji signifikansi dengan uji $\mathrm{F}$ dapat terlihat pada tabel di bawah.

\section{Tabel 5}

\section{Hasil Uji Signifikansi Menggunakan Uji F} ANOVA $^{\mathrm{a}}$

\begin{tabular}{|l|r|r|r|r|r|}
\hline Model & Sum of Squares & df & Mean Square & F & Sig. \\
\hline 1 Regression & 813.524 & 4 & 203.381 & 43.525 & $.000^{\text {b }}$ \\
Residual & 1144.812 & 245 & 4.673 & & \\
Total & 1958.336 & 249 & & & \\
\hline
\end{tabular}

a. Dependent Variable: $Y$

b. Predictors: (Constant), X4, X1, X3, X2

Tabel di atas menunjukkan bahwa nilai $F_{\text {hitung }}$ adalah sebesar 43,525 dimana nilai ini lebih besar dari $\mathrm{F}_{\text {tabel }}$ dengan 250 responden dan taraf kesalahan sebesar $5 \%$ yaitu 3,032. Hipotesis secara simultan dalam penelitian ini adalah:

$\mathrm{H}_{0}: \mathrm{F}_{\text {hitung }}<\mathrm{F}_{\text {tabel}}$, Tidak terdapat pengaruh yang signifikan dari kualitas atribut produk pariwisata terhadap keputusan berkunjung wisatawan ke Kabupaten Sumedang.

$\mathrm{H}_{\mathrm{a}}: \mathrm{F}_{\text {hitung }}>\mathrm{F}_{\text {tabel }}$, Terdapat pengaruh yang signifikan dari kualitas atribut produk pariwisata terhadap keputusan berkunjung wisatawan ke Kabupaten Sumedang.

Sehingga $\mathrm{H}_{0}$ ditolak dan $\mathrm{H}_{\mathrm{a}}$ diterima, artinya terdapat pengaruh yang signifikan dari kualitas atribut produk pariwisata terhadap keputusan berkunjung wisatawan ke Kabupaten Sumedang. 


\section{SIMPULAN}

Berdasarkan seluruh paparan sebelumnya, dapat diambil beberapa kesimpulan dalam penelitian ini yaitu terdapat pengaruh yang signifikan kualitas atribut produk pariwisata terhadap keputusan berkunjung wisatawan ke Kabupaten Sumedang. Hubungan antara kedua variabel tersebut adalah kuat dengan persentase pengaruh kualitas atribut produk pariwisata terhadap keputusan berkunjung adalah sebesar 41,5\%. Pengaruh tertinggi adalah hospitality, diikuti dengan facilities, transportations dan yang paling rendah namun juga tetap signifikan adalah attractions.

Implikasi dari hasil penelitian ini yang menunjukkan bahwa hospitality (keramahtamahan dan penerimaan) memiliki pengaruh terbesar adalah seluruh pemangku kepentingan atas kepariwisataan Sumedang perlu saling bekerjasama agar wisatawan merasa sangat betah dengan keramahtamahan dan penerimaan seluruh individu yang tinggal di Sumedang. Selain itu pengaruh yang tidak kalah tinggi adalah fasilitas dan transportasi dibandingkan atraksi. Sehingga berdasarkan pengaruh tersebut, untuk Kabupaten Sumedang, wisatawan menilai lebih penting untuk meningkatkan keramahtamahan, fasilitas dan sistem transportasinya dibandingkan atraksinya itu sendiri.

\section{DAFTAR PUSTAKA}

Bowie, D., \& Francis, B. (2004). Hospitality Marketing An introduction. Italy: Elsevier Butterworth-Heinemann.

Buhalis, D. (2000). Marketing the competitive destination of the future", Tourism Management, 21 (1), 97-116

Goeldner, C, R., \& Ritchie, J, R, B. (2009). Tourism, Principles, Practices, Philosophies, Eleventh Edition. United States of America: John Wiley \& Sons, Inc.

Holloway, J, C, H, C., \& Davidson, R. (2009). The Business of Tourism, 8th Edition. England: Pearson Education Limited

Lancaster, G., \& Reynolds, P. (2005). Management of Marketing. Great Britain: Elsevier Butterworth-Heinemann

Mill, R, C. (2010). Tourism, The International Business. Dari http://docs.globaltext.terry.uga.edu:8095/anonymous/webdav/Tourism\%20th e\%20International\%20Business/Tourism\%20The\%20International\%20Busi ness.pdf 
Perda No. 2 Tahun 2008 Tentang Rencana Pembangunan Jangka Panjang Daerah (RPJPD) Tahun 2005-2025

Pike, S. (2008). Destination Marketing, An Integrated Marketing Communication Approach. USA: Elsevier Inc.

Silalahi, Ul. (2012). Metode Penelitian Sosial. Bandung: Refika Aditama.

Solomon, M, R. (2013). Consumer Behavior, Buying, Having, and Being Tenth Edition. United States of America: Pearson Education, Inc.

Utama, I Gusti Bagus R., \& Mahadewi, Ni Made, E. (2012). Metodologi Penelitian Pariwisata dan Perhotelan. Yogyakarta: Penerbit Andi.

Vanhove, N. (2005). The Economics of Tourism Destinations. Great Britain: Elsevier Butterworth-Heinemann. 